\title{
Do Lanice conchilega (sandmason) aggregations classify as reefs? Quantifying habitat modifying effects
}

\author{
Marijn Rabaut $\cdot$ Magda Vincx $\cdot$ Steven Degraer
}

Received: 30 August 2007 / Revised: 16 May 2008 / Accepted: 26 May 2008 / Published online: 31 October 2008

(C) Springer-Verlag and AWI 2008

\begin{abstract}
The positive effects of the tube dwelling polychaete Lanice conchilega for the associated benthic community emphasizes this bio-engineer's habitat structuring capacity (Rabaut et al. in Estuar Coastal Shelf Sci, 2007). Therefore, L. conchilega aggregations are often referred to as reefs. The reef building capacity of ecosystem engineers is important for marine management as the recognition as reef builder will increase the protected status the concerned species. To classify as reefs however, bio-engineering activities need to significantly alter several habitat characteristics: elevation, sediment consolidation, spatial extent, patchiness, reef builder density, biodiversity, community structure, longevity and stability [guidelines to apply the EU reef-definition by Hendrick and Foster-Smith (J Mar Biol Assoc UK 86:665-677, 2006)]. This study investigates the physical and temporal characteristics of high density aggregations of $L$. conchilega. Results show that the elevation and sediment consolidation of the biogenic mounds was significantly higher compared to the surrounding unstructured sediment. Areas with L. conchilega aggrega-
\end{abstract}

Communicated by K. Reise.

M. Rabaut $(\bowtie) \cdot$ M. Vincx

Marine Biology Section, Biology Department,

Ghent University (UGent), Sterre Campus Krijgslaan 281-S8,

9000 Ghent, Belgium

e-mail: Marijn.Rabaut@UGent.be

M. Vincx

e-mail: Magda.Vincx@UGent.be

S. Degraer

Management Unit of the Mathematical Model of the North Sea, Royal Belgian Insitute of Natural Sciences, Gulledelle 100, 1200 Brussels, Belgium

e-mail: Steven.Degraer@mumm.ac.be tions tend to be extensive and patchiness is high (coverage 5-18\%). The discussion of present study evaluates whether L. conchilega aggregations can be considered as reefs (discussing physical, biological and temporal characteristics). Individual aggregations were found to persist for several years if yearly renewal of existing aggregations through juvenile settlement occurred. This renewal is enhanced by local hydrodynamic changes and availability of attaching structures (adult tubes). We conclude that the application of the EU definition for reefs provides evidence that all physical and biological characteristics are present to classify $L$. conchilega as a reef builder. For temporal characteristics, this study shows several mechanisms exist for reefs to persist for a longer period of time. However, a direct evidence of long-lived individual reefs does not exist. As a range of aggregation development exists, 'reefiness' is not equal for all aggregations and a scoring table to quantify $L$. conchilega reefiness is presented.

Keywords Lanice conchilega $\cdot$ Reef characteristics . Reefiness $\cdot$ Tube dwelling polychaete

\section{Introduction}

Structures that reach only a few centimeters into the water column represent important habitats for a variety of marine organisms while dimensions of biogenic structures in marine ecosystems are generally of a lower order of magnitude than their terrestrial counterparts (e.g. forests) (Watling and Norse 1998). They may provide refuge from predation, competition and physical as well as chemical stresses, or may represent important food resources and critical nursery or spawning habitats. Habitat structures and heterogeneity influence the faunal abundance, species richness 
and species composition of invertebrate and fish communities (Turner et al. 1999; Koenig et al. 2000). Emergent features provide a structural complex framework that constitutes an important organizing aspect and is critical to the functioning of many ecosystems (Jones et al. 1994).

Persistent emergent structures in aquatic environments are often referred to as 'biogenic reefs'. Because of their important ecological functions, marine reefs have received considerable attention, both from scientists and policy makers. Though intuitively the concept is easily understood, several definitions are still being applied. In the framework of the EU Habitats Directive (EEC/92/43), a definition of reefs is provided by the Interpretation Manual of European Union Habitats and is as follows in the last updated version (EUR 27): "Reefs can be either biogenic concretions or of geogenic origin. They are hard compact substrata on solid and soft bottoms, which arise from the sea floor in the sublittoral and littoral zone. Reefs may support a zonation of benthic communities of algae and animal species as well as concretions and corallogenic concretions." (European Commission DG Environment 2003, 2006, 2007). Holt et al. (1998) refer to a broader definition of reefs (both rocky reefs as biogenically induced reefs) that was proposed by Brown et al. (1997). This definition was used to select Special Areas of Conservation in the UK in the framework of the Habitats Directive and was later altered by Holt et al. (1998) by adding that the unit should be substantial in size and should create a substratum which is reasonably discrete and substantially different from the underlying or surrounding substratum.

The common tube-dwelling polychaete Lanice conchilega is a well-known and widely distributed bio-engineer in soft bottom environments (Rabaut et al. 2007). The physiology, tube structure (Ziegelmeier 1952; Jones and Jago 1993), hydrodynamic influence (Eckman 1983; Heuers et al. 1998; Dittmann 1999), as well as the occurrence of $L$. conchilega aggregations (Carey 1987; Hartmann-Schröder 1996) have already been described at length. The tube aggregations are known to have positive consequences for the distribution and abundance of infaunal species in intertidal and subtidal areas by influencing the habitat structure (Carey 1987; Feral 1989; Zühlke et al. 1998; Dittmann 1999; Zühlke 2001; Callaway 2006; Rabaut et al. 2007; Van Hoey 2006). However, there is still uncertainty about the 'reef building' capacity of this ecosystem engineer. Holt et al. (1998) for instance discuss benthic species as reef builders and state explicitly that they will not include aggregations of $L$. conchilega yet because it is not known how stable they are and whether they are sufficiently solid or altered to qualify as biogenic reefs. This indicates that it is still undecided whether $L$. conchilega classifies as a reef builder. It is, however, important to evaluate the reef building capacity of ecosystem engineers as the recognition as reef builder will increase the protected status of the concerned species [e.g. reefs are listed under Annex I of the EC Habitats Directive EEC/92/43 as a marine habitat to be protected by the designation of Special Areas of Conservation (SACs)].

This study evaluates the 'reef like' features of $L$. conchilega aggregations for which the recommendations on how to interpret and apply the EU reef definition are used (Hendrick and Foster-Smith 2006). 'Reef-like' features fall in three characteristic groups, following Hendrick and Foster-Smith (2006): (1) physical characteristics: elevation, sediment consolidation, spatial extent and patchiness; (2) biological characteristics: biodiversity and community structure; and (3) temporal characteristics: longevity and stability. Few authors refer to the physical characteristics of L. conchilega aggregations (Carey 1987), except for the change in sedimentary composition (Van Hoey 2006; Rabaut et al. 2007).This paper studies the habitat modifying capacity of the ecosystem engineer $L$. conchilega and aims to evaluate whether it classifies as a reef builder. This is done through the quantification of the physical properties and the temporal stability of aggregations of the species. The discussion evaluates whether $L$. conchilega aggregations exist that could qualify as reefs by bringing together all 'reef-like' characteristics. Moreover, this paper aims to design a scoring system for reef characteristics which allows evaluating the reefiness of $L$. conchilega aggregations in subtidal areas.

\section{Materials and methods}

Aggregations of $L$. conchilega occur mainly in subtidal areas, but intertidal aggregations close to the MLWS line do exist. The physical characteristics of these intertidal aggregations are assumed to be comparable with the subtidal ones as remote sensing imagery of $L$. conchilega aggregations is very similar in both zones (Degraer et al. 2008). Therefore, field data was gathered in the intertidal zone. Measurements were done in the Bay of Heist, at the interface of the Flemish beach reserve and the adjacent Belgian integral marine reserve (Fig. 2), where L. conchilega aggregations of approximately $1-12 \mathrm{~m}^{2}$ alternate with tubefree areas in this intertidal zone, generating a surface structure of gentle mounds and shallow depressions (Fig. 1). All measurements were done during May and June 2006 in eleven different delineated aggregations (replicates) that were randomly chosen and in $L$. conchilega free areas next to each aggregation.

To test whether differences in physical characteristics exist, measurements were performed in aggregations of different tube worm densities. Densities were determined by counting tubes with visible fringes (Van Hoey et al. 

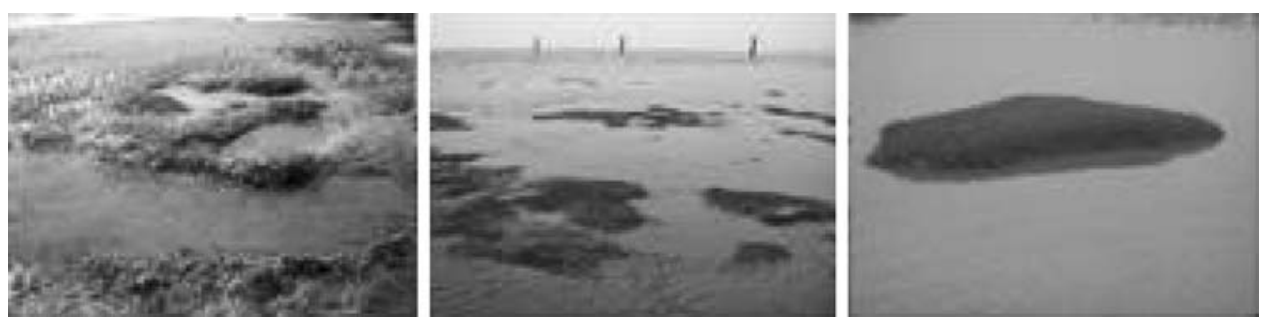

Fig. 1 Pictures of the low intertidal zone of the beach reserve Bay of Heist. Lanice conchilega aggregations of approximately $1-12 \mathrm{~m}^{2}$ alternate with tube-free areas in this intertidal zone, generating a surface structure of gentle mounds and shallow depressions

Fig. 2 Location of the Belgian part of the North Sea (above left); location of the Flemish beach nature reserve Bay of $\mathrm{He}-$ ist (above right); and location of beach area with high density aggregations of Lanice conchilega. Indication of the 11 aggregations that were studied (below right)






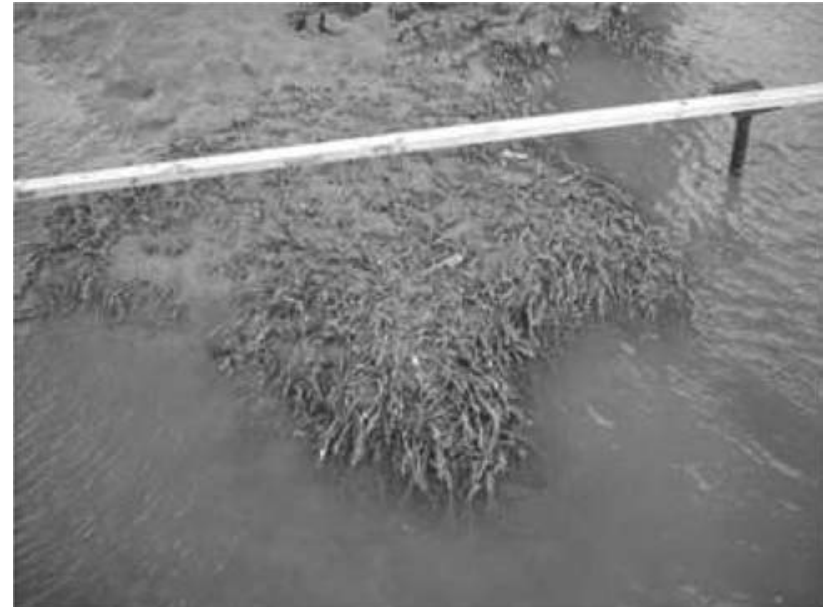

Fig. 3 Methodology to determine the relative height differences of individual aggregations: the vertical distance to the horizontal conduit was measured every $10 \mathrm{~cm}$

2006) in five replicate quadrants of $10 \mathrm{~cm}^{2}$ in each replicate aggregation. These density measurements were used to link to the physical characteristics (either directly or through the use of density classes: 500, 500-1,500, >1,500 ind $\mathrm{m}^{-2}$ ). The physical characteristics measured are elevation, sediment consolidation, spatial extent and patchiness (based on Hendrick and Foster-Smith 2006). The elevation of the aggregations was measured in a relative manner, i.e. the elevation differences to the nearest $0.5 \mathrm{~cm}$ from one side of the reef to the other side (parallel to the water line) (Fig. 3). In other words, height above the surrounding sediment surface level was measured. These measurements were also done in the same zone, but with no L. conchilega present. The difference between the elevation of the biogenic mounds and the elevation of the areas without $L$. conchilega was tested with a Mann-Whitney $U$ test.

The field vane test is commonly used for determination of undrained shear stress in fine-grained soils (Ahnberg et al. 2004). A shear vane is developed to measure sediment stability rapidly in a way that enables repeated measures. The instrument is portable, hand deployed and consist of a vane attached to a torque meter (Leeuwe et al. 2005). In present study, a small portable shear vane with a diameter of $49 \mathrm{~mm}$, a penetration depth of $5 \mathrm{~mm}$ and an accuracy of $0.01 \mathrm{~kg} \mathrm{~cm}^{-2}$ (i.e. $0.98 \mathrm{mbar}$ ) was used. In the eleven delineated aggregations, five replicate measurements were done. For each of these replicates, a measurement was done just outside each aggregation (i.e. L. conchilega free areas). Differences between the two groups of measurements (inside versus outside) were tested with a Mann-Whitney $U$ test. The spatial extent of the $L$. conchilega zone was also measured in the Bay of Heist. The patchiness of the reefs occurring in the investigated zone was based on the delineation of individual aggregations of $L$. conchilega as detected through high resolution side scan sonar imagery (Klein 3000 series, $445 \mathrm{kHz}$ ). The imagery is a reflection of the acoustic energy that is backscattered from the seafloor and is displayed in different levels of grey. The differences in backscattering are in decreasing order determined by (1) the geometry of the sensor-target system, (2) the angle of incidence of each beam, local slope, etc., (3) the physical characteristics of the surface, such as the micro-scale roughness, and (4) the intrinsic nature of the surface (composition, density, relative importance of volume versus surface diffusion/scattering for the selected frequency) (Blondel and Murton 1997). The imagery of a subzone of the total L. conchilega area of the Bay of Heist was analyzed using the geographical information system (GIS) ArcView 9.2. The surface of individual reefs was calculated as well as the surface of the subzone in which they occurred. The percentage coverage was calculated and provided together with the information on individual aggregation surface (average, minimum, maximum) an indication of patchiness.

The relation between local hydrodynamic changes induced by the L. conchilega aggregations and the renewal of these aggregations by juveniles was tested with artificial $L$. conchilega aggregations in the study area. During the recruitment period of $L$. conchilega, five replicates of $1 \mathrm{~m}^{2}$ with 1,000 artificial tubes have been created in the Bay of Heist to mimic hydrodynamic impacts of the biogenic mounds. Wooden sticks with an inner diameter of three $\mathrm{mm}$ were used. The length of the tubes was $22 \mathrm{~cm}$ and they were place $18 \mathrm{~cm}$ deep into the sediment (i.e. four $\mathrm{cm}$ above the sediment surface). Plots were created on $t_{-1}$ in zones with none or very few $L$. conchilega specimens. At next spring tide $\left(t_{0}\right)$, a small scale hydrodynamic pattern was apparent: in each replicate plot several small areas could be identified with a higher sedimentation rate. In each artificial plot of $1 \mathrm{~m}^{2}$, three replicate surface areas of $10 \mathrm{~cm}^{2}$ were chosen as high sedimentation zones and three as low sedimentation zones. In these zones, density of newly settled juveniles was quantified for each defined area of $10 \mathrm{~cm}^{2}$. These replicates remained the same within one plot during the experiment at later measurements. In order to reduce time effects, $t_{-1}$ was not the same spring tide date for all plots. As the monitored areas within each plot were the same, the data were analyzed using repeated measures ANOVA.

\section{Results}

Mean densities of 2,104 \pm 219 SE individuals per $\mathrm{m}^{2}$ were found (maximum 3,640 $\pm 323 \mathrm{SE}$; minimum $620 \pm 177$ $\mathrm{SE})$. Different measurements were done for all density classes, in order to link this with the other reef characteristics. 
The L. conchilega biogenic mounds in the Bay of Heist reached an average elevation of $8.4 \pm 1.8 \mathrm{~cm}$. The highest elevation was $16.5 \mathrm{~cm}$. There was a significant $(P<0.0001)$ difference in elevation when the aggregations were compared with zones outside the aggregations. No significant difference was however, observed between aggregations of different densities $(P>0.28)$. Shear stress inside the aggregations is far higher than immediately outside the aggregations $(P<0.0001)$ (Fig. 4). A clear correlation also appears between the shear stress and the densities of $L$. conchilega tubes $(R=0.82, P<0.0001)$. Kruskal Wallis test for differences in shear stress between different density groups $\left(<500,500-1,500,>1,500\right.$ ind $\left.\mathrm{m}^{-1}\right)$ reveals significant differences $(P<0.01)$ which mark the importance of high densities to locally consolidate the sediment.

The spatial extent of the intertidal area in the Bay of Heist, where L. conchilega aggregations occur, was estimated to be $220,000 \mathrm{~m}^{2}$ and was found near the low water tide line (Fig. 2). Based on the side scan sonar imagery the aggregations had an average surface of $1.37 \mathrm{~m}^{2}\left( \pm 2.02 \mathrm{~m}^{2}\right.$ $\mathrm{SD})$, the largest aggregation reached a surface of $12.31 \mathrm{~m}^{2}$ whereas the smallest identifiable aggregation was only $0.05 \mathrm{~m}^{2}$ (Fig. 5). The coverage was calculated to be $18.4 \%$.

The artificial tube reef experiment in the intertidal zone shows that a changing hydrodynamic pattern on a very local scale occurs as a result of the presence of adult $L$. conchilega. This pattern leads to a settling advantage for juvenile L. conchilega, as is visible in Fig. 6. Comparison between areas showing clear sedimentation and areas without sedimentation within each artificial plot shows a signifi-

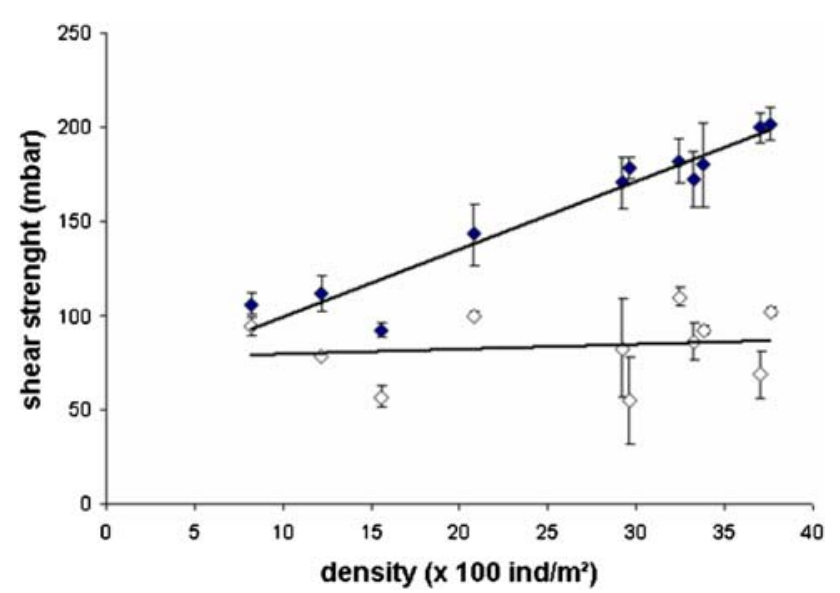

Fig. 4 Shear stress. The shear stress of 11 aggregations of different densities was measured. Measurements were done inside the aggregation (filled diamond) as well as immediately beside each aggregation (open diamond). Shear stress is significantly higher inside the aggregation compared with shear stress outside the aggregation. The shear stress of high density aggregations is significantly higher than the shear stress of low density aggregations. Visualized error bars are standard errors, calculated on five replicate measurements per aggregation



Fig. 5 Patchiness. A subzone (shaded area) with identified Lanice conchilega aggregations (black) as apparent from the side scan sonar imagery. The relative coverage area (ratio of Lanice conchilega aggregations over the total area in which they occur) is $18.4 \%$ and the average aggregation reaches an area of $1.37 \mathrm{~m}^{2}\left(\min 0.05 \mathrm{~m}^{2}\right.$; $\max$ $12.31 \mathrm{~m}^{2}$ )

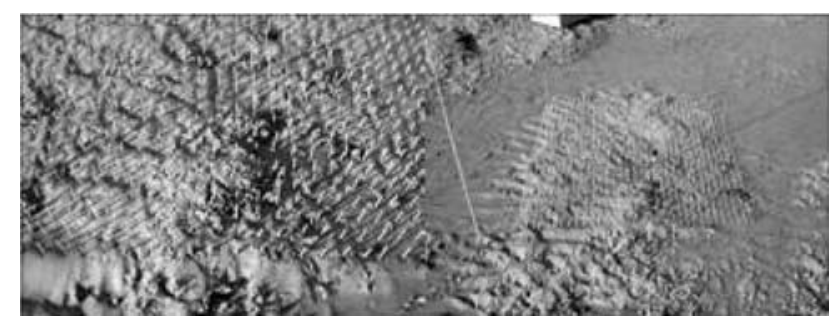

Fig. 6 Artificial tube experiment. Pictures showing local sedimentation patches that proved to enhance settlement of juvenile Lanice conchilega significantly shortly after sedimentation

cantly higher settling $(P<0.001)$ in the areas with sedimentation shortly after $t_{0}$ (Fig. 7). However, this initial settling advantage was not sustained during subsequent spring tides.

\section{Discussion}

This paper quantified physical properties and studied mechanisms that enhance long term stability of L. conchilega aggregations. The habitat modifying capacity of the ecosystem engineer L. conchilega is discussed in this section. This information is used to evaluate whether this particular species classifies as a reef builder. Following the recommendations of Hendrick and Foster-Smith (2006) to interpret and apply the EU reef definition, the results presented in this 


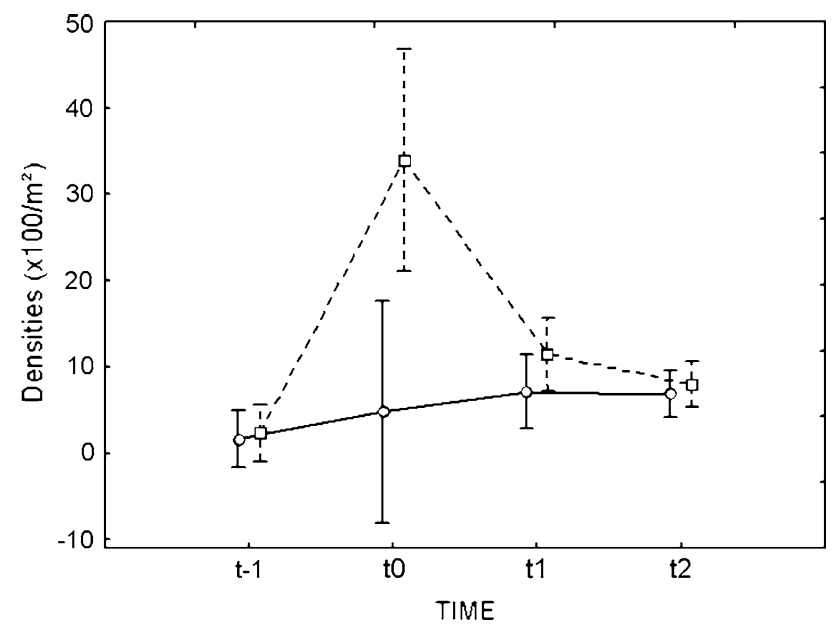

Fig. 7 Juvenile settlement enhanced through changing hydrodynamics. Within artificial tube aggregations, densities are followed up during four spring low water tides both in areas were sedimentation occurred (square) and in areas without sedimentation (circle). Sedimentation zones enhance the settlement of juvenile Lanice conchilega significantly shortly after sedimentation. This pattern was consistent as not all plots were placed at the same spring tide. This settlement enhancement was not sustained for a longer period of time as no real adult tubes to attach on were present in the artificial tube plots

paper will be discussed together with the existing literature on the physical, biological and temporal features of $L$. conchilega aggregations.

Recorded densities of $L$. conchilega vary widely and reach densities of around 5,000 ind $/ \mathrm{m}^{2}$ (though occasionally higher densities can be found). Density is the characteristic that relates to many of the other reef characteristics. Information on the density of $L$. conchilega provides insight in the physical characteristics (e.g. the consolidation of the sediment), probably also in the temporal characteristics and in the other biological characteristics. Results on the quantification of the densities in the aggregations show that the normal density range is covered, except for the very high densities.

The elevations in the intertidal zone of the Bay of Heist are not very pronounced, but do differ significantly from the surrounding sediment. The report of Holt et al. (1998) refers to L. conchilega aggregations reaching elevations of $45 \mathrm{~cm}$ (intertidal area at North Norfolk coast) while Carey (1987) reports intertidal L. conchilega aggregations of up to $80 \mathrm{~cm}$. However, more pronounced elevations could have been enhanced by other organisms, as the described cementation of the macroalgae Enteromorpha sp. and Polysiphonia sp. on Tentsmuir Beach (Carey 1987). The results also suggested that this elevation occurs with relatively low $L$. conchilega densities (500 ind $\mathrm{m}^{-2}$ ) and remains the same for increasing densities. There is currently no information available on the elevation of subtidal aggregation, though the very similar side scan sonar imagery of both intertidal and subtidal aggregations (Degraer et al. 2008) suggests that they are of the same order of magnitude.

The consolidation of the sediment by L. conchilega is reflected in the increased shear stress in $L$. conchilega aggregations. Moreover, there was a clear correlation with the density of L. conchilega. On the one hand, this effect could be related to the drainage effect of the tubes, which would explain the correlation; on the other hand the effect might be explained by the change in sedimentary composition (Rabaut et al. 2007). The clear correlation with the tube density can possibly be used as a proxy for this consolidation in the future.

Concerning the spatial extent and patchiness, Ropert and Dauvin (2000) reported an estimated colonized subtidal area of more than $2,000,000 \mathrm{~m}^{2}$ in the Bay of Veyst, whereas on the Gröniger plate in Germany several thousands of $\mathrm{m}^{2}$ of colonized intertidal sand flat have been reported (Zühlke 2001). Presented results show that the areas of occurrence of dense aggregations are generally extended. They are larger in subtidal than in intertidal areas (Degraer et al. 2008). The extensive areas in which $L$. conchilega aggregations occur is of importance as a more extensive area has a greater conservation significance than a smaller one (Hendrick and Foster-Smith 2006).

Patchiness relates to the variation in individual aggregation surface and, more importantly, to the coverage percentage of reefs within a reef zone. Average, minimum and maximum aggregation surface provide insight in the variation of aggregations. This study showed that the variation is high and that it can be measured based on side scan sonar imagery. With this technique it was also relatively straightforward to calculate the coverage of the aggregations within a certain area. The same technique could be used in subtidal areas though to date, no such quantification has been performed.

Concerning the biological implications of $L$. conchilega, the impact of $L$. conchilega on the biodiversity was demonstrated by Zühlke (2001) (intertidal) and Rabaut et al. (2007) and Van Hoey et al. (2008) (subtidal). Table 1 provides some (maximum) values as published by the respective authors. The impact of L. conchilega on the diversity indices was calculated by taking the ratio of the biodiversity value when $L$. conchilega is present over the value in the same region when $L$. conchilega is absent. For this relative impact, it is clear that the impact in the subtidal areas is higher.

Furthermore, in the study of Zühlke (2001) species richness was found to be generally higher in L. conchilega aggregations than in areas free of $L$. conchilega for data over several years. Diversity indices taking account of evenness indicated significantly higher diversity in $L$. conchilega aggregations than in references. However, no correlation was found between the density of $L$. conchilega 
Table 1 Biological characteristics as taken from different authors

\begin{tabular}{llll}
\hline & $\begin{array}{l}\text { Intertidal } \\
\text { Zühlke } \\
(2001)\end{array}$ & $\begin{array}{l}\text { Subtidal } \\
\text { Van Hoey } \\
\text { et al. }(2008)\end{array}$ & $\begin{array}{l}\text { Subtidal } \\
\text { Rabaut } \\
\text { et al. }(2007)\end{array}$ \\
\hline $\begin{array}{l}\text { L. conchilega density } \\
\left(\text { max ind } \mathrm{m}^{-2}\right)\end{array}$ & 4,000 & 5,000 & 5,000 \\
$N 0(\max )$ & 10.5 & 29 & 35.6 \\
$N 0 / N 0 \mathrm{ref}$ & 1.2 & 2.4 & 2.8 \\
$N 1$ & 5.1 & 10 & \\
$N 1 / N 1$ ref & 1.3 & 1.7 & \\
$\begin{array}{l}\text { Abundance } \\
\quad\left(\text { max ind } \mathrm{m}^{-2}\right)\end{array}$ & 72,000 & 4,500 & 8,000 \\
$\begin{array}{l}\text { Abund/Abund ref } \\
\text { ANOSIM }\end{array}$ & 2 & 9 & 5 \\
\hline
\end{tabular}

In order to compare different values, only data related to biological reef characteristics were extracted from the publications. Only maximums are presented here to illustrate that differences occur for different regions (figures are indicative as they are presented as round numbers, deduced from published graphs). The effect of $L$. conchilega on the diversity indices ( $N 0$ total number of species; $\mathrm{N} 1 \exp \left(\mathrm{H}^{\prime}\right)$, with $\mathrm{H}^{\prime}$ the Shannon diversity) was calculated by taking the ratio of the biodiversity value when Lanice conchilega is present over the value in the same region when L. conchilega is absent ('reference', indicated as 'ref')

tubes and species richness or individual abundances. The community structure of associated fauna was found to be significantly different from $L$. conchilega-free areas in three out of four investigated years when $L$. conchilega was actually present. Rabaut et al. (2007) found that species richness within the aggregations increased together with $L$. conchilega densities. In addition, a positive correlation between the steadily increasing macrobenthic densities and densities of $L$. conchilega could be found. The study of Van Hoey et al. (2008) showed that the implications of subtidal L. conchilega were the same for a large geographic area and in different kinds of sediment types. In this study, a significant and positive correlation between the benthic density and the density of $L$. conchilega has been described as well as increasing species richness with increasing density of $L$. conchilega. However, this trend was found to be inconsistent: after reaching a certain density of $L$. conchilega the number of associated species no longer augmented, which is probably related to competition for space. This finding is an indication that very high density aggregations are of less value than intermediate density aggregations.

Also community structure was proved to change when $L$. conchilega was present. ANOSIM results prove this difference in community structure is highly significant (Table 1). Moreover, Rabaut et al. (2007) confirmed that communities differed gradually according to increasing abundances of $L$. conchilega density (a so called 'Babushka' type of community structure). This effect is related to the increasing structural complexity when the density of this tube builder increases which in turn creates more niches and conse- quently more food provision. The species-specific explanation for this general increase has been described for different densities of $L$. conchilega aggregations (Rabaut et al. 2007).

Temporal characteristics of the aggregations are difficult to estimate without long-term monitoring of individual aggregations. Long-lived, stable biogenic concretions are expected to have a greater value in respect of the aims of the Habitats Directive than an otherwise comparable habitat of ephemeral nature (Holt et al. 1998; Hendrick and FosterSmith 2006). In her long term analysis of intertidal aggregations, Zühlke (2001) suggested that $L$. conchilega aggregations are ephemeral in intertidal areas. This unsustainability of aggregations on tidal flats could be related to the dynamic characteristics of this environment and to freezing temperatures in winter (e.g. Strasser and Pieloth 2001; Zühlke 2001). In the absence of storms or strong winters, L. conchilega aggregations could probably survive for several years. In subtidal environments, hydrodynamic stress is lower and the water layer protects this environment against steep drops in temperature. Moreover, individual mounds that are biogenically constructed by $L$. conchilega are described to persist for more than 1 year (Carey 1987).

Because L. conchilega is a short living species (Van Hoey 2006), the biogenic structures can only persist through efficient renewal of juveniles each year. One of the mechanisms of how juveniles settle more successfully on existing aggregations on adults was described in an intertidal study of Callaway (2003).

Moreover, the results of present study showed that hydrodynamic changes induced by biogenic mounds make the pelagic larvae to settle on existing aggregations. This significant settling effect was not sustained over time. We hypothesize that the artificial tubes used in the hydrodynamic experiment were too smooth and that no juveniles could attach to them. We reason that juveniles were able to settle on the hydrodynamic mounds, but could not settle into the sediment because of the absence of real adult tubes. We suggest that hydrodynamic changes induced by $L$. conchilega aggregations induce first settlement, while in a second phase adult tubes serve as an ideal surface to attach before they settle in the sediment. The initial settling effect was reproduced at different times during the recruitment period, which made the observed results reliable. Therefore, it is assumed that individual aggregations of high density aggregations can persist for several years, though the maximum lifespan is difficult to estimate. Large scale destruction because of storms or general degradation after a failed reproduction period is probable to occur in some years. This might lead to the conclusion that these structures are ephemeral in nature but it appears to be widely accepted that in that respect all reef building organisms are 
ephemeral by nature (Hendrick and Foster-Smith 2006) as the vulnerability to natural (e.g. storms) or anthropogenic (e.g. fisheries) events increases with the emergent character.

The relation between the presence of adult tubes and the settling advantage of juveniles suggest that there is a relation between the density of the aggregations and the longevity, as the chance of being renewed with juveniles is higher for high density aggregations.

\section{'Reefiness' of L. conchilega aggregations}

Holt et al. (1998) disqualified L. conchilega aggregations as reefs because it is "unlikely that they are sufficiently solid or altered to qualify as biogenic reefs" and because it is "not known how seasonal/stable these features are". However, the application of the EU Habitats Directive definition of 'reefs' (habitat 1170 of Annex I)—using the guidelines provided by Hendrick and Foster-Smith (2006)—provided clear evidence that all characteristics needed to classify biogenic structures as reefs are present in the case of high density aggregations of L. conchilega.

We acknowledge however, that a range of values exists for the different reef characteristics. The formation of so called L. conchilega reefs is a continuous process which starts from 'L. conchilega bed' formation with a low value for the physical, biological and temporal reef criteria and ends with very pronounced biogenic structures that are very 'reefy'. Not all reef characteristics will increase at the same time and might in some cases even be adversary. In order to differentiate between L. conchilega aggregations or areas, we combined our findings in order to define the 'reefiness' (sensu Hendrick and FosterSmith) of L. conchilega reefs wherever they are found in subtidal areas. Therefore, we have made a scoring system (Table 2) for a variety of reef characteristics. As aggregations mainly occur in subtidal areas, this scoring table is constructed for subtidal reefs.

In the first place the scoring system aims to provide insight in the range in which different reef characteristics for L. conchilega are to be situated. The values are based on the results presented in this paper. This scoring system can be applied through the quantification of each characteristic for a given subtidal $L$. conchilega reef area. Some characteristics are difficult to quantify but several characteristics are correlated (as mentioned above). The L. conchilega density score relates positively to several other characteristics, though biodiversity score drops when aggregations reach very high densities (adversary reef characteristics). To combine these different scores in one overall 'reefiness' score for the area, the individual scores should be weighted for importance and reliability. The more data and accuracy is available for the value of a reef feature, the more weight it receives. It is also suggested by Hendrick and FosterSmith (2006) to give the greatest weighting to elevation, area and temporal stability. The value of the scoring system lies in the possibility to compare different areas where $L$. conchilega occurs.
Table 2 Scoring system for a variety of reef characteristics, as adapted from the $S$. spinulusa scoring system, proposed by Hendrick and Foster-Smith (2006), p. 667

\begin{tabular}{|c|c|c|c|}
\hline & \multicolumn{3}{|l|}{ Characteristic score } \\
\hline & $\begin{array}{l}\text { Low } \\
0\end{array}$ & $\begin{array}{l}\text { Medium } \\
50\end{array}$ & $\begin{array}{l}\text { High } \\
100\end{array}$ \\
\hline \multicolumn{4}{|l|}{ Elevation score } \\
\hline \multicolumn{4}{|l|}{ Sediment consolidation score } \\
\hline Shear vane stress & $\sim 1 \mathrm{~kg} \mathrm{~cm}^{-2}$ & $\sim 1.5 \mathrm{~kg} \mathrm{~cm}^{-2}$ & $\sim 2 \mathrm{~kg} \mathrm{~cm}^{-2}$ \\
\hline \multicolumn{4}{|l|}{ Area score } \\
\hline Extent of total area & $1,000 \mathrm{~m}^{2}$ & $50,000 \mathrm{~m}^{2}$ & $>100,000 \mathrm{~m}^{2}$ \\
\hline Average area of individual reefs & $\sim 1 \mathrm{~m}^{2}$ & $\sim 2 \mathrm{~m}^{2}$ & $2-10 \mathrm{~m}^{2}$ \\
\hline \multicolumn{4}{|l|}{ Patchiness score } \\
\hline $\begin{array}{l}\text { Percentage cover of patches } \\
\text { within the total area }\end{array}$ & $\sim 5 \%$ & $5-10 \%$ & $>10 \%$ \\
\hline \multicolumn{4}{|l|}{ Lanice conchilega Density score } \\
\hline $\begin{array}{l}\text { Average density } \\
\text { of } L \text {. conchilega }\left(/ \mathrm{m}^{2}\right)\end{array}$ & $\sim 500$ individuals & $500-1,500$ individuals & $>1,500$ individuals \\
\hline \multicolumn{4}{|l|}{ Biodiversity score } \\
\hline Species richness $(\mathrm{S})$ & $\sim 18$ & $\sim 25$ & $>30$ \\
\hline Margalef's index (d) & $\sim 2$ & $\sim 2.5$ & $>3$ \\
\hline Longevity score & 1 year & 2 years & $>2$ years \\
\hline
\end{tabular}




\section{Conclusions and outlook}

The physical characteristics of $L$. conchilega aggregations are presented in this study for intertidal systems. These results suggest that the characteristics as described by Hendrick and Foster-Smith (2006) are fulfilled. Besides, literature (e.g. Zühlke 2001; Rabaut et al. 2007; Van Hoey et al. 2008) shows that the biological characteristics are well known and that the characteristics to classify $L$. conchilega aggregations as reefs are fulfilled. It is, however, still difficult to estimate what the spatial extent and patchiness is of these systems in subtidal areas. This is an important knowledge gap that should receive attention in the future. Finally, reefs should be stable enough to persist for several years (temporal reef-characteristics). For the latter, it is known that aggregations can sometimes persist longer but that they are generally ephemeral in intertidal areas (Zühlke 2001). However, subtidal systems are expected to be more stable and some mechanisms exist for the aggregations to be replenished by juveniles. One of these mechanisms has been described in present study. Here also, only long-term monitoring with advanced remote sensing techniques will provide insights in the longevity of individual aggregations.

Acknowledgments The authors thank the assistance during the field work of Hans De Wandeler, Hannes Hoste, Lieven Therry, Peter Vermeiren, Bart Beuselinck, Jeroen Speybroeck and Liesbeth Hiele. Technical support was provided by Jürgen Verstraeten through the production of experimental material. We are very grateful for the provision of side scan sonar imagery by Isabelle Dufour and Vera Van Lancker (Renard Centre for Marine Geology, Ghent University) and for the use of the portable shear vane provided by Francesc Montserrat of the Netherlands Institute of Ecology (Centre for Estuarine and Marine Ecology). Furthermore, we thank the Flemish authorities (LNE) for the permission to perform scientific work in the nature reserve Bay of Heist (special thanks to Jean-Louis Herrier and Koen Maréchal). We thank Liesbeth Hiele for the valuable linguistic comments. This research was carried out within the Ghent University BBSea project (contract no. GOA 01G00705; http://biology.ugent.be/bbsea) and within the WESTBANKS project (understanding benthic, pelagic and air-borne ecosystem interactions in shallow coastal seas; http:// www.vliz.be/projects/westbanks) which is supported by the Belgian Science Policy (BELSPO; contract no. SD/BN/01A) in the frame of the SSD programme. The authors acknowledge the support by the MarBEF Network of Excellence 'Marine Biodiversity and Ecosystem Functioning' (http://www.marbef.org) which is funded by the Sustainable Development, Global Change and Ecosystems Programme of the European Community's Sixth Framework Programme (contract no. GOCE-CT-2003-505446). This publication is contribution number MPS-08031 of MarBEF. The authors are grateful for all valuable comments to the early draft provided by the participants during the MarBEF theme 2 workshop on ecosystem engineers. We are very grateful to Ulrike Braeckman for the scientific argumentations and discussion while we thank Francis Kerckhof for his view on the semantic aspect of the word reef. We are indebted to three anonymous referees and we thank the editors Karsten Reise and Tjeerd Bouma for the valuable comments. The first author acknowledges an aspirant grant provided by the Flemish Fund for Scientific Research (FWO-Vlaanderen), Belgium.

\section{References}

Ahnberg H, Larsson R, Berglund C (2004) Influence of vane size and equipment on the results of field vand tests. Geotech Geophys Site Characterization 1-2:271-277

Blondel P, Murton B (1997) Handbook of seafloor sonar imagery. Wiley, London

Brown AE, Burn AJ, Hopkins JJ, Way SF (1997) The habitats directive: selection of Special Areas of Conservation in the UK. JNCC Report No. 270. Joint Nature Conservation Committee, Peterborough (as cited in Holt et al. 1998)

Callaway R (2006) Tube worms promote community change. Mar Ecol Prog Ser 308:49-60

Callaway R (2003) Juveniles stick to adults: recruitment of the tubedwelling polychaete Lanice conchilega (Pallas 1766). Hydrobiologia 503:121-130

Carey DA (1987) Sedimentological effects and palaeoecological implications of the tube-building polychaete Lanice conchilega Pallas. Sedimentology 34:49-66

Degraer S, Moerkerke G, Rabaut M, Van Hoey G, Du Four I, Vincx M, Henriet JP, Van Lancker V (2008) Very high resolution side-scan sonar mapping of biogenic reefs of the tube-worm Lanice conchilega. Remote Sensing Environ. doi:10.1016/j.rse.2007.12.012

Dittmann S (1999) Biotic interactions in a Lanice conchilega-dominated tidal flat. In: Ditmann S (ed) The Wadden Sea ecosystem. Stability properties and mechanisms. Springer, Berlin, pp 43-49, $153-162$

Eckman JE (1983) Hydrodynamic processes affecting benthic recruitment. Limnol Oceanogr 28:241-257

Feral P (1989) Influence des populations de Lanice conchilega (Pallas) (Annelida, Polychaeta) sur la sedimentation sableuse intertidale de deux plages bas-normandes (France). Bull Soc Géol France 8:1193-1200

Hartmann-Schröder G (1996) Annelida.. Borstenwürmer, Polychaeta Tierwelt Deutschlands Teil 58. Gustav Fischer Verlag Jena, $648 \mathrm{pp}$

Hendrick FJ, Foster-Smith RL (2006) Sabellaria spinulosa reef: a scoring system for evaluating 'reefiness' in the context of the habitats directive. J Mar Biol Assoc UK 86:665-677

Heuers J, Jaklin S, Zühlke R, Dittmann S, Günther C, Hildenbrandt H, Grimm V (1998) A model on the distribution and abundance of the tube-building polychaete Lanice conchilega (Pallas, 1766) in the Intertidal of the Wadden Sea. Verhandlungen Gesellschaft Ökol 28:207-215

Holt TJ, Rees EI, Hawkins SJ, Seed R (1998) Biogenic reefs. an overview of dynamic and sensitivity characteristics for conservation management of marine SACs. Scottish Association for Marine Science (UK Marine SACs Project), vol IX, $170 \mathrm{pp}$

Jones CG, Lawton JH, Shachak M (1994) Organisms as ecosystem engineers. Oikos 69:373-386

Jones SE, Jago CF (1993) In situ assessment of modification of sediment properties by burrowing invertebrates. Mar Biol 115:133-142

Koenig C, Coleman F, Grimes C, Fitzhugh G, Scanlon K, Gledhill C, Grace M (2000) Protection of fish spawning habitat for the conservation of warm temperate reef fish fisheries of shelf edge reefs of Florida. Bull Mar Sci 66:593-616

van Leeuwe MA, Morgan G, Brockman C (eds) (2005) A system of hierarchical monitoring methods of assessing changes in the biological and physical state of intertedal areas (HIMOM). Book of Protocols, $199 \mathrm{pp}$

Rabaut M, Guilini K, Van Hoey G, Vincx M, Degraer S (2007) A bioengineered soft-bottom environment: the impact of Lanice conchilega on the benthic species-specific densities and community structure. Estuar Coastal Shelf Sci. doi:10.1016/j.ecss.2007.05.041 
Ropert M, Dauvin JC (2000) Renewal and accumulation of a Lanice conchilega (Pallas) population in the Baie des Veys, Western Bay of Seine. Oceanol Acta 23:529-546

Strasser M, Pieloth U (2001) Recolonization pattern of the polychaete Lanice conchilega on an intertidal sand flat following the severe sinter of 1995/96. Helgol Mar Res 55:176-181

Turner SJ, Thrush SF, Hewitt JE, Cummings VJ, Funnell G (1999) Fishing impacts and the degradation or loss of habitat structure. Fish Manag Ecol 6:401-420

Van Hoey G (2006) Spatio-temporal variability within the macrobenthic Abra alba community, with emphasis on the structuring role of Lanice conchilega. PhD Thesis, UGent

Van Hoey G, Vincx M, Degraer S (2006) Some recommendations for an accurate estimation of Lanice conchilega density based on tube counts. Helgol Mar Res 60:317-321

Van Hoey G, Guilini K, Rabaut M, Vincx M, Degraer S (2008) Ecological implications of the presence of the tube building polychaete Lanice conchilega on the soft-bottom benthic ecosystems. Mar Biol (in press)

Watling L, Norse EA (1998) Disturbance of the Seabed by mobile fishing gear: a comparison to forest clearcutting. Conserv Biol 12:1180-1197

Ziegelmeier VE (1952) Beobachtungen über den Röhrenbau von Lanice conchilega (Pallas) im Experiment und am natürlichen Standort. Helgoländer Wissenschaftliche Meeresuntersuchungen, pp $108-129$

Zühlke R (2001) Polychaete tubes create ephemeral community patterns: Lanice conchilega (Pallas, 1766) associations studied over six years. J Sea Res 46:261-272

Zühlke R, Blome D, van Bernem DH, Dittmann S (1998) Effects of the tube-building polychaete Lanice conchilega on benthic macrofauna and nematodes in an intertidal sandflat. Senckenb Marit 29:131-138 